\title{
OS RELATOS DE LUIZ ANTÔNIO DE OLIVEIRA MENDES SOBRE A SAÚDE DA POPULAÇÃO ESCRAVA: DO TRAFICO NA ÁFRICA AO CATIVEIRO NO BRASIL (1793)
}

\author{
Alisson Eugênio*
}

\begin{abstract}
Resumo: Neste artigo serão analisadas as considerações de um intelectual lusobrasileiro, de origem baiana, Luiz Antônio de Oliveira Mendes, a respeito das condições de saúde dos escravos, desde o tráfico até o cativeiro no Brasil, e suas propostas para melhorar tais condições, com o objetivo de saber como ele fundamentou suas críticas e qual estratégia utilizou para convencer os agentes da escravidão da necessidade de mudar a maneira como eles tratavam os indivíduos a ela submetidos. A análise é feita a partir do Artigo "Memórias sobre os escravos e tráfico de escravatura entre a costa da África e o Brasil" de 1793, publicado somente em 1813.
\end{abstract}

Palavras-chave: Escravidão, Tráfico de Escravos, Saúde.

Abstract: This paper examines the considerations of a Luzo-Brazilian intellectual, from Bahia, Luiz Antônio de Oliveira Mendes, about the health condition of the slaves, and from trafficking to the captivity in Brazil, and proposals to improve such conditions, in order to know how he based his criticism and what strategy used to convince the agents of slavery from the need to change the way they treated individuals subjected to it.

Keywords: Slavery, Slave trade, Health.

\footnotetext{
* Professor Adjunto de História na Universidade Federal de Alfenas. E-mail: alissoneugenio@yahoo.com.br
} 
| 202 |

Os relatos de Luiz Antônio..

\section{Introdução}

O texto "Memórias sobre os escravos e tráfico de escravatura entre a Costa da África e o Brasil" de 1793, publicado somente em 1813 de Luis de Antônio de Oliveira apresenta uma dura crítica à maneira como os escravos eram tratados desde o tráfico até o cativeiro, durante o império português. Segundo, Mendes (1991), um tropel de desgraças abateu-se sobre milhões de africanos, arrastados pelo tráfico de escravos para a América, desde a sua captura em solo materno, até seus últimos dias no cativeiro. Como consequência disso, para o autor tamanho foi o infortúnio dos indivíduos submetidos a esse trágico processo de deslocamento humano, que os sobreviventes dele "se podiam chamar homens de ferro ou de pedra” (Mendes, pp. 41-2). Com essas considerações, Mendes (1991) expressa o pasmo de uma geração de letrados, sintonizados com o ideário crítico do Iluminismo, diante das calamidades geradas pela escravidão. Quando Mendes desenvolveu essas ideias, essa forma de organização da produção e a sua fonte abastecedora de mão-de-obra, o tráfico transatlântico, estavam sendo questionadas desde pelo menos a publicação da clássica obra do Barão de Montesquieu: Do espírito das leis (1749). $\mathrm{O}$ período se remete ao auge da Era das Luzes. O movimento ilustrado que o gerou desenvolveu uma nova sensibilidade, diante dos dramas da existência humana, sustentado no conceito de humanidade e no sentimento de compaixão embutidos no adjetivo humanitário dela derivado. Não se quer afirmar que as críticas de Mendes ilustrado luso-brasileiro, natural da Bahia (1748-1817), que estudou direito, filosofia e medicina na Universidade de Coimbra entre os anos de 1770 e 1780, tenham sido motivadas por tal sentimento. Mas seu texto expressa bem uma forma padrão de narrativa surgida na esteira do Iluminismo, cujos temas estão relacionados com os infortúnios da vida cotidiana; narrativa humanitária, conforme a definiu Thomas Laqueur: abordagem extraordinariamente minuciosa dos sofrimentos e da morte de pessoas comuns (1992, p. 240). 
Havia decorrido quase três séculos de migração forçada de parte considerável da população negra africana para o Novo Mundo, quando Mendes elaborou na sua Memória uma narrativa humanitária comovente sobre as etapas de conversão do negro à escravidão. No entanto, seu texto não é um testemunho fiel da realidade (Silva, 202, p. 255), embora seus argumentos estejam fundados nela, pois seu objetivo expresso era o de contribuir para transformá-la. Assim, pode ser interpretado como um longo panfleto contra os males do cativeiro. Por isso, há quem defenda que o autor foi antiescravista, ao desejar a extinção "para sempre da escravidão dos pretos a todos odiosa", em uma das passagens polêmicas da versão original de sua Memória, suprimidas ou alteradas na versão impressa (Oda, 2007, p. 359).

Seja como for, aqui seu escrito será interpretado como um recurso literário, destinado a sensibilizar os negociantes do tráfico, os senhores dos escravos e o Estado para melhorar as condições de vida do que ele considerou "a porção mais desgraçada da espécie humana" (Mendes, 1991, p. 1). Para isso, elaborou uma narrativa marcada por frases de efeito, por abundância de adjetivos macabros e por histórias trágicas. Assim, construiu uma imagem perversa da escravidão e dos seus agentes, como forma de cobrar destes uma nova postura em relação ao tratamento dos cativos, condizente com os ideais humanitários então em voga.

\section{Adentrando as "memórias"}

Ao todo o texto de Mendes (1991) tem seis capítulos. O primeiro dedicado à geografia do tráfico e aos costumes da África negra. O segundo tem como foco as modalidades legais e ilegais da conversão de africanos à escravidão. $O$ terceiro descreve o processo de condução deles desde a África até a América. $\mathrm{O}$ quarto e o quinto, respectivamente, abordam as suas doenças agudas e as suas doenças crônicas, e o último apresenta meios preventivos e curativos para evitar os altos índices de mortalidade que elas provocavam. 
| 204 |

Os relatos de Luiz Antônio..

A impressão que Mendes (1991) passa sobre as regiões de onde se arrastavam a maioria dos africanos para os portos americanos é de uma África selvagem, de clima ardente e doentio, recortada por diversos rios, por sertões secos e mesmo assim habitados pelas mais variadas comunidades, que viviam sustentadas pela caça, pela pecuária e agricultura de subsistência, por um artesanato de consumo local e, dependendo do lugar, de um comércio mais intenso com regiões vizinhas, ou às vezes até com regiões distantes, e mineração. Essa mesma África, descrita etnocentricamente com o olhar de um ilustrado europeu que, se muito, conheceu o seu litoral, era habitada, segundo ele, por povos na maioria das vezes bárbaros, de costumes gentílicos, como o da poligamia, que andavam quase nus, viviam em palhoças precárias, muito mal mobiliadas, em cujo centro havia uma fogueira destinada ao preparo das refeições compostas principalmente de feijão, legumes e carne, acrescida de algumas frutas e farinha. Esses povos mesmo vivendo em um clima tão adverso e de forma precária, são considerados na Memória robustos, saudáveis e felizes, pois, viviam livres, ocupados com suas tarefas cotidianas, e quando não estavam a elas entregues, tomavam suas bebidas, como a aluá (um fermentado de cereal), com suas danças, seus instrumentos musicais, suas cantigas e religiões (Mendes, 1991, p. $9-17)$.

Assim pulsava a vida no imenso e complexo mosaico social africano, conforme a narrativa de Mendes, quando os portugueses, e posteriormente outras nações europeias, romperam a faixa mediterrânea, contornando a costa oeste do continente, desde o cabo Bojador (alcançado em 1434) até o cabo da Boa Esperança (contornado em 1497). Depois disso, o dia a dia de grande parte das populações da Africa negra mudaria sensivelmente. A chegada dos europeus interferiu em diversos campos das relações humanas. Uma delas é a escravidão.

Essa forma de organização das relações sociais de produção já existia em numerosas sociedades africanas desde a Antiguidade. Mas, salvo exceções, ela não existiu como fator estrutural da economia local. Em outras palavras, na maior parte 
das aldeias seu funcionamento era complementar ao trabalho de natureza geralmente familiar. Os escravos pertenciam a famílias e não a indivíduos. Tinham personalidade étnica normalmente conservada e não legava sua condição jurídica servil para os seus descendentes.

Segundo descrição de Mendes, a escravidão era admitida como punição a crimes, como forma de saldar dívidas e como destino dos derrotados em guerra. Nessas duas primeiras modalidades, havia um juiz, Soba, responsável pelo julgamento dos réis, e somente após sua sentença (podia ser a morte, no caso dos assassinos) se submetiam ao cativeiro. Na última modalidade, a sorte é que decidia quem iria perder a vida ou a liberdade (Mendes, 1991, p. 18-9). Nesse caso podiam mesmo ser entregues aos mercadores de escravos que, desde pelo menos os tempos de Roma, comboiavam cativos pelo Mediterrâneo e pelo Índico.

Na Idade Moderna, a colonização mercantil da América acabou gerando grande demanda de mão de obra que, em algumas partes, após esgotadas as possibilidades de aproveitar os nativos para o trabalho em grande escala, foi satisfeita com escravos africanos até aproximadamente meados do século XIX. Os portugueses foram os primeiros a se servirem deles, levando-os para o seu reino como serviçais. Posteriormente os usaram nas suas primeiras experiências com a fabricação de açúcar em ilhas conquistadas próximas ao litoral africano ainda no século $X V$. Por fim, quando introduziram a cultura do mesmo produto no Brasil e, principalmente, quando descobriram ouro, diamantes e outras pedras preciosas no seu interior, os levaram em grande massa para o outro lado do Atlântico. Nesse último momento, o deslocamento humano forçado alcançou tamanha proporção, que sua viabilidade e eficiência somente poderiam ser garantidas com a montagem de um empreendimento empresarial intercontinental enorme e complexo conhecido como tráfico negreiro.

O sucesso desse empreendimento dependeu de uma rede de agentes de uma ponta a outra do oceano (Florentino,1997). Dos comboieiros, que conduziam negros do mais remoto interior da África, aos leiloeiros, que vendiam os lotes de africanos nos 
| 206 |

Os relatos de Luiz Antônio...

mercados dos portos americanos, havia uma longa jornada a ser seguida pelos que tiveram a infelicidade de ser arrancados da liberdade. Mendes (1991) descreve essa jornada com traços agudos de dramaticidade, para formar a opinião de que os negros eram cruelmente tratados, desde o início do trajeto, no coração da África, até o seu destino final nos cativeiros da América, e que isso aumentava demasiadamente o número de mortos durante esse longo deslocamento, provocando prejuízos tanto econômicos quanto morais para todos que estavam envolvidos com a escravidão.

O tráfico para as colônias do Novo Mundo começou a ser organizado no século XVI. Até meados do século XIX, quando foi extinto, ele conduziu mais de 10 milhões de almas para diversos pontos do novo continente. Somente para o Brasil foram aproximadamente 4 milhões. ${ }^{1}$ Toda essa população não foi produto apenas de justiça dos sobas, nem do equilíbrio instável da geopolítica interna da África e muito menos das calamidades climáticas responsáveis, em alguns lugares, por prolongadas secas que impunham desastrosas epidemias de fome, ao ponto de famílias inteiras se entregarem aos comerciantes de escravos. Ela foi, na maior parte, vítima de raptos organizados por grupos de indivíduos bem armados e apoiados por autoridades locais, sobretudo dos reinos, impérios e confederações tribais, que tiveram no comércio negreiro grande fonte de riqueza, o que cada vez mais incentivou comunidades a entrarem em guerra umas com as outras, não mais pelas suas divergências, mas para simples captura de vidas destinadas a alimentar a escravidão na América (Florentino, 1997 e Karash, 2000).

Periodicamente, à medida que levas de indivíduos iam sendo acumuladas nos centros de confinamento espalhados por várias regiões africanas, uma caravana liderada por um comboieiro passava para recolhê-los, sob a forma de escambo,

\footnotetext{
${ }^{1}$ Há muitas divergências sobre o número de africanos transportados para o Brasil, conforme argumenta diversos autores. Entre eles Hebert Klein (2004, p.155).
} 
elevá-los ao centro de distribuição, como Luanda, capital da Angola, geralmente grandes armazéns no litoral, onde eram revendidos para os agentes incumbidos de atravessá-los pelo oceano. Essa primeira etapa do tráfico negreiro durava meses, pois se levava muito tempo para os comboios serem formados na quantidade mais lucrativa possível. Nesse momento, os escravos eram presos pelo pescoço em uma grande e grossa corrente, chamada libambo. Marchavam horas a fio, carregando os suprimentos para sua manutenção e artigos negociáveis pelo caminho. Essa manobra era perigosa, pois, além de longa, comia-se pouco (por questão de redução de custo) e dormia-se ao relento. Dessa forma, muitos não resistiam e acabavam adoecendo e até morrendo. A esse respeito, Mendes relata:

\begin{abstract}
Ainda que na jornada diga o escravo, que está doente, que não pode prosseguir nela, ele é tido por mentiroso; Em vez de se tratar do curativo da doença, que ele tenha, é espancado, para o fazerem marchar: de sorte, que metidos os escravos em o libambo, ou eles devem prosseguir na jornada, e destino, quer possam, quer não possam; ou devem perecer no libambo, como várias vezes sucede (Mendes, 1991, p. 22).
\end{abstract}

Os que sobreviviam a essa primeira parte eram negociados no litoral, onde ficavam armazenados por até três meses à espera dos negociantes de além-mar. Ali o tratamento por eles recebido continuava muito a desejar, pois a comida permanecia escassa e pouco nutritiva e as roupas não eram renovadas. Os efeitos trágicos dessa etapa, somadas aos da primeira, eram as inúmeras mortes até o embarque. Klein estima que até $30 \%$ da mortalidade dos escravos ocorria antes mesmo deles serem embarcados (2004, p. 157). Mendes (1991) fornece sobre isso um relato com dados alarmantes. Segundo ele, era tão grande a quantidade de mortes na escravaria durante a espera dos compradores encarregados de conduzi-la ao seu destino, que saindo de Luanda em cada ano de dez a doze mil escravos, muitas vezes sucederia a situação de 
| 208 |

Os relatos de Luiz Antônio..

somente transportarem "de seis a sete mil para o Brasil" (Mendes, 1991, p. 23).

O próximo passo dessa diáspora era o confinamento dos africanos nos navios negreiros. Essas embarcações atravessavam o oceano durante aproximadamente três séculos com os seus porões abarrotados de carne humana, que a América aguardava sedenta para devorar. Eram conduzidos por uma tripulação chefiada por um capitão responsável pelo escambo com os agentes do tráfico posicionados na costa africana. Em troca dos negros entregavam armas, pólvora, tecidos e artefatos diversos (ferramentas, espelhos, etc.) se viessem da Europa. Se viessem do Brasil, a permuta se fazia com junco, aguardente, açúcar e farinha de mandioca.

Feita a transação, era hora de partir. A viagem demorava de quarenta dias a três meses. Dependia da origem da partida e do ponto final do desembarque, da tonelagem da embarcação, da sua tecnologia de navegação e da sua necessidade de escalas para abastecimento. Enquanto ela durava, as mercadorias vivas ficavam amontoadas nos porões, onde a ventilação era mínima, tornando o ar insalubre, com quase nenhum espaço para mobilidade, com água e comida insuficientes e, às vezes, de má qualidade, e com os mesmos farrapos com os quais estavam "embrulhadas" quando foram entregues às caravanas dos comboieiros na primeira parte do tráfico.

Mendes (1991) relata que "essa porção da humanidade desgraçada", após tantas privações da jornada inicial, do armazenamento anterior à travessia oceânica, "que se vai apurando de mão em mão, com resistência a tantos contratempos, de que vai escapando pela força da robustez", depois de ser "entregue aos capitães dos navios (...), é metida e fechada debaixo da escotilha" (Mendes, 1991, p. 23). Nesse local ficava até o fim do percurso, sendo escoltada de vez em quando para a superfície a fim de tomar um pouco de sol e ar fresco.

Como todo negociante, os atravessadores de escravos também procuraram reduzir os custos da sua mercadoria. Com esse objetivo, seguiam três regras básicas: “1a) o de permutar, e de fazer a sua escravaria pelo mais barato que possa ser; 2a) 
o de meter e o de transportar em um navio quanto lhes seja possível a maior porção dela; 3a) que com ela se despenda o menos que possa ser no seu transporte." (Mendes, 1991, p. 24). O resultado disso não poderia ser lisonjeiro. A mortalidade havia de ser muito alta, principalmente nas primeiras décadas do tráfico, quando a taxa de óbitos girava em torno de $20 \%$ em média por navio. Posteriormente, esse percentual foi caindo até atingir aproximadamente $6 \%$, a partir das décadas iniciais do século XIX. Essa redução, embora expressiva, ainda não foi suficiente para que o índice de mortalidade ficasse dentro do padrão aceitável na época; algo em torno de $2 \%$. No entanto, contribuiu para que mais negros chegassem vivos à América. Para isso, leis foram criadas, desde as primeiras leis portuguesas como a de 1664 até as leis inglesas do final do século XVIII, arbitrando a quantidade de indivíduos relativa ao peso e tamanho das embarcações.

Os mortos durante a travessia tinham o mar como sepultura. Nele se atiravam os corpos sem cerimônia ou ritual de deferência às almas que eles abrigaram. Por mais resistentes que os escravos fossem as doenças muitas vezes os venciam dadas as condições de acomodação nos "tumbeiros", conforme Conrad (1985) adjetivou os navios negreiros. A propósito, não é por acaso que o imaginário popular é marcado por uma visão dantesca dessas embarcações. Os autores empenhados em combater o tráfico, ou ao menos melhorar as suas condições, como Mendes, junto com os abolicionistas de diversas extirpes, acabaram por produzir relatos horrendos desse abominável negócio para convencer o Estado a extingui-lo Um dos relatos mais apaixonantes a esse respeito foi feito pelo Cirurgião Naval Thomas Nelson. Em seu diário, publicado em 1846, ele relata a situação da escravaria do navio Dois de Fevereiro:

Amontoados no convés, e obstruindo as passagens em ambos os lados, agachados, ou melhor curvados, trezentos e sessenta e dois negros, com doença, deficiência e miséria estampadas com intensidade e de tal forma dolorosa que excedia qualquer poder de descrição. A um canto... um grupo de miseráveis estirados, muitos nos últimos estágios da exaustão e 
$|210|$

Os relatos de Luiz Antônio..

\begin{abstract}
todos cobertos com as pústulas da varíola. Observei que muitos deles tinham rastejado até o lugar em que a água havia sido servida, na esperança de conseguir um gole do líquido precioso; mas incapazes de retornarem a seus lugares, jaziam prostrados ao redor da tina. Aqui e ali, em meio ao aglomerado, havia casos isolados da mesma doença repugnante em sua forma confluente ou pior, e casos de extrema emaciação e exaustão, alguns em estado de completo estupor, outros olhando penosamente ao redor, apontando com dedos para suas bocas crestadas. ... Em todos os lados, rostos esquálidos e encovados tornados ainda mais hediondos pelas pálpebras intumescidas e pela ejeção pluriforme de uma violenta oftalmia, da qual parecia sofrer a maioria; além disso havia figuras reduzidas a pele e osso, curvadas numa postura que originalmente foram forçados a adotar pela falta de espaço, e que a debilidade e rigidez das juntas forçaram-nos a manter (Apud Conrad, 1985, p. 56 ).
\end{abstract}

Segundo os estudiosos do assunto, essa imagem deprimente não pode ser generalizada para todas as embarcações. Em muitas delas, realmente, o quadro foi mesmo trágico, principalmente se a travessia tivesse durado além demais do previsto, se os embarcados já estivessem mais frágeis do que normalmente estavam ao serem retirados dos depósitos de negros no litoral africano e se as calamidades no navio tivessem extrapolado os limites do suportável. Afinal, cada escravo, por mais barato que custasse ao traficante, se não chegasse vivo e em condições de ser negociado nos mercados americanos, lhe renderia prejuízo de aproximadamente $0,67 \%$ da carga total (Klein, 2004, p. 132). Por essa razão, tinham de esmerar-se para reduzir suas perdas, que eram elevadas devido aos efeitos do impacto de toda a cadeia de deslocamento até os navios e dos cálculos para a redução dos custos de seu transporte marítimo. Em outras palavras, embora a travessia fosse brutal e, em muitos casos, sanguinária, seria incoerente na racionalidade econômica dos empresários do tráfico 
que sua mercadoria ficasse entregue a tantos sofrimentos sem intervenção nenhuma por parte deles.

Quando os navios chegavam ao seu destino, começava a terceira e última etapa do tráfico: a exposição dos africanos nos mercados de escravos. O desembarque era feito em pequenos barcos a remo, logo após a permissão das autoridades. Ao desembarcarem, eles passavam por uma contagem pelo pessoal da alfândega, por razões tributárias e, em seguida, eram postos à venda. Em diversas ocasiões ela ocorria rapidamente, pois vários compradores já estavam à espera para escolher os negros mais robustos. Não raramente, lotes inteiros se arrematavam em leilões diretamente pelos grandes proprietários locais ou seus prepostos, quando a demanda exigisse. Os que sobravam a esse primeiro impulso mercantil eram depositados em locais onde pudessem ser preparados para uma nova exposição.

Por uma questão novamente de custo, nessa etapa o tratamento dos escravos continuava precário. Pois, "por se querer liquidar a negociação pela menor despesa, a escravatura se conserva sem novo vestuário, e encontra economia de escassas rações", que denuncia Mendes o autor da Memória, elas "são feitas daqueles mantimentos que o capitão fez durar por providência para maior tempo de viagem" (Mendes, 1991, p. 25).

Um dos mercados de africanos mais frequentados na América foi o do Valongo, que funcionou entre 1758 e 1831, em uma das maiores cidades receptoras do tráfico negreiro desde o auge da extração de pedras preciosas em Minas Gerais em meados do século XVIII: O Rio de Janeiro. Diversos viajantes retratam esse local. Uma das mais lúgubres descrições dele foi elaborada pelo naturalista alemão George Wilhelm Freireyss em 1814.

As doenças eram inúmeras e pareciam relacionadas à fadiga, às misérias e aos mau tratos que sofreram na viagem e de que são consequências. Muitos morrem de febres infecciosas, disenteria, escorbuto, nostalgia, etc., antes de chegarem ao novo senhor, mas também muitas vezes logo depois. A varíola vitima também anualmente uma grande porção dos infelizes, não 
$|212|$

Os relatos de Luiz Antônio...

\begin{abstract}
obstante, porém, podem ser vacinados gratuitamente, para o que o governo mantém postos vacínicos em muitos lugares. A indiferença, porém dos traficantes pela vida dos escravos é tão grande que não se utilizam destes postos úteis, e até aqueles que conduzem escravos para o interior saem da capital sem terem vacinado um só preto. Não se pode negar, todavia, que a maior parte sucumbe de falta de cuidados e bons médicos (1992, p. 130).
\end{abstract}

A falta de cuidados médicos aludidos no depoimento de Freireyss (1992) é devido à carência de profissionais da medicina e dos preços por eles cobrados. Isso encarecia o custo da escravaria, o que os mercadores procuravam evitar. Assim, os escravos doentes geralmente recebiam atendimento dos barbeiros sangradores, os quais na maioria das vezes submetiam os pacientes a sangrias (extração de sangue para eliminar a corrupção que, de acordo com uma das teorias médicas em voga, provocava uma série de enfermidades), o que os debilitava ainda mais.

Naquele mercado, a espera por compradores era muito desconfortável. O chão se fazia de cama, a comida, como sempre, aquém das necessidades nutricionais e o que sobrava das vestes, depois do longo deslocamento, mal dava para cobrir as partes íntimas. Tudo isso tornava os negros mais propensos às doenças, que os levavam aos montes para os braços da morte antes de serem vendidos. Tanto que, com o enorme aumento do desembarque negreiro nos anos 1720, motivado pela expansão do extrativismo aurífero nas vilas mineiras, foi construído um novo cemitério, nas proximidades do Valongo. Da sua inauguração até seu fechamento (1722-1830) milhares de africanos foram enterrados nele. Somente no ano de 1828 foram 2019 indivíduos que, depois da travessia, ali encontraram seu leito derradeiro. Em termos percentuais, estima-se que $4 \%$ dos desembarcados tinha como destino tal cemitério, conhecido como dos pretos novos (Pereira, 2007, p. 112).

No entanto, a mortandade foi bem maior, pois muito dos filhos da África, falecidos antes de se completar o ciclo do tráfico, foram sepultados clandestinamente. No Rio de Janeiro, 
por exemplo, em 1815 o intendente de polícia, Paulo Fernandes Vianna, pediu providências ao juiz criminal contra os abusos a esse respeito cometidos pelos agentes do comércio negreiro num local próximo ao mercado dos pretos novos. Diz ele:

Nos fundos da rua nova de São Joaquim e fundos das casas novamente edificadas nos cajueiros era um pântano que, além de nocivo à saúde pública, ainda de mais a mais é cemitério de cadáveres de negros novos, pela ambição dos homens do valongo que para ali os lançavam a fim de se furtarem da despesa de pagar cemitério (Apud Honorato, 2007, p. 134).

A imensa travessia, para grande parte dos escravos, terminava nas cidades portuárias e suas adjacências. Mas outros tantos ainda deveriam percorrer enormes distâncias até chegarem ao cativeiro. Para o vasto interior do país eram conduzidos outra vez em libambos. Os destinados às montanhas de Minas Gerais precisavam subi-las durante dias e não poucos ficavam pelo caminho, às vezes expostos como banquetes aos abutres.

Ao terminar as gigantescas jornadas percorridas, do seio da África às entranhas da América, quando finalmente os negros encontravam os grilhões do trabalho escravo, o que eles poderiam esperar? Eis a resposta de Mendes:

Desembarcada esta grande porção de escravatura na América, é conduzida para casa de comum senhor, que também o é do navio, e de toda a negociação. Ali para ser vista de todos, são os escravos postos, e mandados assentar em lotes, e com separação dos grandes aos pequenos, das pretas maiores e menores, na rua pela frente da propriedade do senhor; e quando à noite se faz preciso ser recolhida a escravatura, repousa em um grande armazém térreo, que fica por baixo da propriedade senhorial. Quando esta porção de escravatura chega ao Brasil, consigo pensa, e bem, que entrando na terra prometida da abundância, e da fartura, nada deve lhe faltar; porém o contrário lhe sucede, porque por se querer liquidar a negociação 
$|214|$

Os relatos de Luiz Antônio...

pela menor despesa, a mesma escravatura se conserva sem novo vestuário; e encontra a economia de umas escassas rações, que de ordinário são feitas daqueles mantimentos, que o capitão fez durar por providência para maior tempo da viagem (Mendes, 1991, p. 25-26).

O que lhes aguardava eram duras tarefas cotidianas, cumpridas do alvorecer ao crepúsculo, mau tratamento (alimentação inadequada e insuficiente, vestimenta precária, senzalas insalubres e mal equipadas, reduzido tempo de descanso e castigos ocasionais ou mesmo recorrentes se as ordens não fossem satisfatoriamente cumpridas ou se alguma falta mais grave fosse cometida). A consequência disso não poderia ser outra: tornavamse presas fáceis para as doenças, ficando, se afetados por elas, sob a espreita da morte.

$\mathrm{Na}$ condição de desterrados, forçadamente arrancados de suas raízes, o universo da escravidão era um mundo repleto de incertezas. Quase tudo era diferente de sua vida anterior: a religiosidade, a alimentação, as formas de trabalho, as relações de parentesco, entre outros aspectos da vida cotidiana; tudo isso exigiu, lenta, dolorosa e difícil adaptação que transformou a vida em "contínuo martírio", como caracterizou o autor da Memória (Mendes, 1991, p. 26). Conforme ele investigou, "os povos africanos em os países de sua habitação e natalício são muito menos atacados" por doenças, o que "se deve ao ar a que estão acostumados (...), aos seus constantes e certos alimentos, às águas de que usam e a que são habituados." Porém, "eles em mudança, em que encontram novos ares, desacostumadas comidas e outras águas, já são mais acometidos" (Mendes, 1991, p. 28).

\section{As enfermidades descritas por Mendes que acometiam a população escrava}

Entre tantas enfermidades que vitimavam a população cativa, várias se destacam pela sua recorrência e morbidade. 
O autor em questão elenca alguma delas, as classificando em dois grupos: agudas e crônicas.

No primeiro grupo estão todas as enfermidades "que ordinariamente acometem aos pretos escravos, e que são adquiridas nas mudanças dos seus alongados transportes, aonde tudo de mau e contrário à conservação da saúde os persegue" (Mendes, 1991, p. 27). São elas: febres malignas (febre amarela), hemorragias, ou fluxo hemorrágico anal (disenteria), corrupção do bicho (maculo), tosses e constipações, sezões (malária), opilação (ancilostomíase), bexigas (varíola), doença do bicho e carbúnculos (edemas cutâneos).

A primeira delas, a "mais prejudicial das moléstias agudas, que sofrem os pretos escravos", tanto "nos reinos africanos, como quando descem dos seus sertões, na estada dos portos marítimos, no seu transporte, e mesmo no Brasil", são "umas grandes e repentinas febres, bem semelhantes às perniciosas, as quais (...) em poucos dias os matam". Os indivíduos afetados por esta "terrível e destruidora enfermidade", causada por picada de insetos transmissores de um vírus originário de certas espécies de macacos, apresentam "sonolência que, crescendo por efeitos (...) da ardentíssima febre, prostram o enfermo de um tal modo, e este tão veemente, que o entregam a um letárgico, do qual no seu auge se passa para a outra vida". A segunda, o fluxo hemorrágico, "que muito acometem a escravatura, sendo estas as que levam à sepultura grande parte" dela, é a todos conhecida como "mal de Luanda". Essa doença, derivada da contaminação da alimentação, e da água em situações sanitárias insatisfatórias, provoca uma "evacuação contínua, e por efeito dela o intestino reto se dilata, e o ânus se circula com lábios esponjosos, que nascem do interior da via". Em seguida "vem o que se chama do bicho". Trata-se do que na medicina da época se definia como maculo ou corrupção do bicho: uma inflamação entre as porções mais baixas do aparelho digestivo e o ânus, extremamente incômoda, dolorosa e mortífera. "Na ordem das mesmas moléstias agudas, em quarto lugar devem ser postas as infindas constipações e as frequentíssimas e veementes tosses". Estas encontravam terreno fértil para causar os seus 
| 216 |

Os relatos de Luiz Antônio...

estragos na estação do frio, ou nos horários em que a temperatura cai bruscamente, e, principalmente, no "mau trato e falta do vestuário preciso, o que consome e destrói muita escravatura". A próxima é composta pelas "infinitas sezões, que, começando em terçãs e quartãs, com o aumento de horas vindo a acompanhar umas e outras, fazem com que muita escravatura faleça". Todavia, se "os escravos chegam a escapar" delas, neles ainda ficam as opilações que, "dentro de poucos tempos estragando-os, os levam à sepultura, são postas no sexto lugar das enfermidades agudas" (Mendes, 1991, p. 28-29).

A quinta moléstia acima denominada como sezões é a malária. Muito comum nas regiões de densas florestas tropicais, ela tornou-se endêmica no Brasil e foi um dos maiores males da população como um todo. Causada por um protozoário da espécie plasmodium, facilmente encontrado ao sul do Equador, transmitido pela fêmea do mosquito anófeles, provoca grande cansaço, perda de apetite, dor de cabeça e muscular. A isso se acrescentam ataques cíclicos de tremura, febre alta, frio intenso, náusea e vômito. A sexta moléstia acima denominada opilação, também endêmica no nosso país, é muito comum em populações pobres facilmente atacadas por verminoses, devido às condições sanitárias em que vivem. Depois de longos debates, os médicos tropicalistas descobriram tratar-se da ancilostomíase, originada de um nematóide hematófago (ancilóstomo) que ataca a mucosa intestinal para saciar seu voraz apetite por sangue, causando anemia aos seus hospedeiros. A sétima das doenças agudas "vem a ser as bexigas" (nome popular da varíola) "e o sarampo, que os experientes dos países africanos têm visto repetir diversas vezes, já em seus sertões, já nos presídios, já em portos marítimos, já no embarque e ainda mesmo no Brasil". Por serem altamente contagiosas, "começando em um só escravo se comunicam a todo o lote da escravatura", provocam inúmeras perdas de vida. No caso da varíola, com a descoberta de um preventivo, a vacina, no final do século XVIII, houve considerável redução de mortes à medida que foi sendo generalizada, quando as autoridades públicas 
passaram a ofertá-las gratuitamente. ${ }^{2}$ A oitava enfermidade aguda, muito "frequente na Costa da Mina e no Brasil, vem a ser a doença do bicho de outra qualidade". Diferente da anterior, que ataca o intestino reto e o ânus, "este bicho se cria nos corpos dos pretos (...) e de ordinário se acha nos braços e nas pernas. Dada a gravidade dos seus efeitos (inchaço, dor e até gangrena) ele deve ser cuidadosamente extraído com agulha ou alfinete; caso contrário, a vítima ou morre ou fica inutilizada para o trabalho". As últimas são "os carbúnculos ou antrazes, frequentes nos países de nascimento dos escravos, como em portos marítimos, e no Brasil." Essa moléstia, assim denominada por apresentar uma mancha escura nas partes afetadas, é um tipo de edema cutâneo que se manifesta sob a forma de uma grande e incômoda pústula, a qual se curava com aguardente e cauterização (Mendes, 1991, p. 29-31).

O segundo grupo de doenças, classificadas por Mendes como crônicas, é formado por oito males: banzo, sarna, boubas, escorbuto, bicho do pé, lombrigas, hidropsia e ressecação dos bofes (ressecamento de órgãos do sistema digestivo). A primeira delas, ele define da seguinte maneira:

O banzo é um ressentimento estranhado por qualquer princípio, como por exemplo; a saudade dos seus, e da sua pátria; o amor devido a alguém; a ingratidão, e aleivosia, que outro lhe fizera; a cogitação profunda sobre a perda de liberdade; a meditação continuada da aspereza, com que os tratam; o mesmo mau trato, que suportam; e tudo aquilo, que pode melancolizar. É uma paixão de alma, a que se entregam, que só é extinta com a morte (Mendes, 1991, p. 31).

Como exemplo da manifestação da doença depressiva em sua Memória há um relato comovente, obtido de Raimundo Jalama, administrador do contrato das companhias do Pará e Pernambuco

2 Sobre a vacinação contra a varíola, particularmente na população escrava, há pelo menos dois trabalhos: Chalhoub, 1999, pp. 110-13 e Honorato, 2007, pp.120-26. 
$\mid 218$ |

Os relatos de Luiz Antônio...

(criadas por Marquês de Pombal entre 1755 e 1759) por dez anos na cidade de São Paulo de Luanda. Segundo ele entre tantas cargas de africanos remetidos para o Brasil estava uma escrava, com uma filha de aproximadamente 7 anos, "que se entregava a um tal fastio, por efeitos do banzo, que nada queria comer". Ao observar esse comportamento, resolveu investigá-lo e, após insistidas perguntas, veio a saber que "seu marido, a quem tanto amava, a havia dado com ingratidão à dura escravidão, juntamente com sua tão estimada filha". Tendo tomado consciência disso, tentou animá-la com alguns agrados e até promessa de liberdade. Mas nada a tirava daquele melancólico estado, que arrancava das almas mais sensíveis lágrimas de compaixão ao vê-la entregue a tão profunda agonia. "Seus olhos eram como dois rios e de contínuo tinha a cabeça sobre os joelhos". E assim ficou até falecer, deixando sua filha à mercê das incertezas de um mundo injusto e sombrio; o mundo do cativeiro. Sabe-se que ela sobreviveu e foi estimada como "heroína do amor", tendo recebido batismo com simbólico nome de Lucrécia (dama romana raptada por um nobre etrusco que optou pela morte a ser escravizada); uma clara homenagem à sua mãe. ${ }^{3}$ Essa é uma história dramática, das tantas engendradas pela escravidão, que na Memória emerge como uma adaga no coração de quem, por força do cristianismo ou da Ilustração, se sensibilizava com a miséria da existência humana.

A segunda enfermidade crônica, "e de sumo perigo, vem a ser a sarna". De caráter altamente contagioso, ela se propaga facilmente, sobretudo quando as circunstâncias a favorecem, como nas etapas do tráfico nas quais inúmeros negros são reunidos sem as mínimas condições de higiene por tanto tempo. Essa enfermidade distingue-se em duas: a sarna mansa e a brava. Essa última "ocupa o terceiro lugar das doenças crônicas" e "é igualmente epidêmica", mas de outra natureza em relação à anterior por se "tratar de efeito de mal venéreo". Ela, a que "chamam de boubas",

\footnotetext{
${ }^{3}$ Mendes, 1991, p. 31-2. A informação sobre o nome de batismo da filha da escrava falecida encontra-se na versão original de Mendes (Cf: Oda, 2007 p. 356).
} 
se apresenta sob forma de chagas em diversas partes do corpo. A próxima espécie de doenças crônicas, que muito "acomete a escravatura, vem a ser o escorbuto". Essa enfermidade é provocada pela carência de vitamina C. Durante o enorme percurso entre a África e o Brasil, principalmente na etapa da travessia atlântica, a alimentação ficava muito a desejar. Nessa etapa, os alimentos frescos não resistiam muito tempo e o reabastecimento não se fazia rapidamente, e quando ele ocorria, as fontes de vitamina $C$ (frutas cítricas e algumas verduras) não estavam sempre disponíveis. Consequentemente, muitas embarcações chegavam aos portos com grande número de escorbúticos, os quais se conhecia pela pele escamosa, febre, hemorragia e dentes enegrecidos. "Outra espécie de doenças crônicas que muito acometem a escravatura, e vem ocupar o quinto lugar, são os bichos que nascem nas mãos, corpos e com maior força nos pés". Os escravos andavam descalços, por motivo de economia e como marca de sua condição servil. Assim, ficavam expostos ao verme responsável por comichão e, se não fosse expulso, por uma inflamação que poderia causar grandes danos, como a perda de mobilidade, febre, ínguas e fortes dores. Na sequência das doenças crônicas, "que costumam levar grande número da escravatura insensivelmente à sepultura, vem a ser as lombrigas". O diagnóstico feito na época acabou revelando-se equivocado ("relaxação do estômago proveniente do "clima ardente" e das comidas de inferior qualidade que são as que de ordinário têm os escravos"), pois se entendia a formação dessa verminose como resultado de geração espontânea dessas duas combinações, clima quente e má alimentação. Entretanto sua enorme incidência nos cativos é resultado das precárias condições de higiene às quais estavam submetidos. As hidropisias, "por cuja porta vão ter à morte muitos mil escravos" são a sétima das moléstias crônicas. Ela provoca enorme inchaço no ventre e um amarelão nos olhos com grande incômodo para o enfermo, que por isso apresenta movimentos lentos e uma quase letargia. Isso é normalmente resultante da redução ou paralisação das atividades do fígado por má alimentação, ou verminoses (esquistossomose), ou vírus (hepatite) ou por excesso de bebida alcoólica (Mendes, 
$|220|$

Os relatos de Luiz Antônio..

p. 32-3). Quando o consumo exagerado desse tipo de bebida tornava-se diário, Mendesidentifica "aúltima das moléstias crônicas e a mais prejudicial", qual seja, "a que chamam vulgarmente ressecação dos bofes; doença que provém de muita giribita, ou aguardente, e cachaça do Brasil, que de contínuo bebe toda a escravatura". Pois, conforme explica:

\begin{abstract}
A esta se entregam com extremo por três princípios: primeiro; porque vivendo em seu país natalício, aonde há falta dela, e sendo apaixonadíssimos desta bebida, ao depois encontrando-a com abundância, se fartam dela: segundo; porque a debilidade, a frouxidão, e a relação do seu estomago assim o pede: terceiro, porque sendo os escravos nascidos em um país muito mais quente que o Brasil, que demais é assistido de muitas virações, andando muito mal vestidos, sentem frio, e na falta de roupa se entregam a esta bebida, persuadidos de que os aquece; o que sendo momentâneo, continuam na mesma bebida, para sustentarem o pretendido calor, com danificação conhecida das suas entranhas. (Mendes, 1991, p. 34).
\end{abstract}

A parte final da Memória é dedicada aos "meios de se acautelarem, e de se curarem tanto das enfermidades agudas, como crônicas, que acometem e matam os pretos escravos". Nela, o autor apresenta o último, o mais longo e o mais importante capítulo do seu texto. Nele sugere que "os pretos escravos da África, desde o instante de seu infeliz cativeiro, encontrariam a melhora, ou pelo menos a conservação da sua saúde, se também encontrassem outro discernimento" os agentes da escravidão desde o tráfico até o cativeiro (Mendes, 1991, p. 34-5). Tal discernimento refere-se a uma mudança de mentalidade por parte de tais agentes no tocante ao tratamento dos escravos, que era determinado pela lógica predominanteno negócio negreiro e no cativeiro em relação ao preço dos escravos. Para os traficantes, quanto menor o gasto feito com eles até a venda, maior seria o lucro. Para os grandes proprietários coloniais, o dispêndio com a manutenção da escravaria deveria ser conformado com o custo do seu empreendimento e com 
a expectativa do tempo de exploração da força de trabalho dela e com as próprias circunstâncias do mercado de consumo de seus produtos.

O novo discernimento, que Mendes procurou contribuir para fomentar nos agentes da escravidão, deveria ser pautado em diversas posturas orientadas nos apelos humanísticos da Ilustração e pela racionalidade econômica neo-mercantilista, ${ }^{4} \mathrm{em}$ voga no século XVIII, que pregava, entre outras coisas, o fim do desperdício de vidas para se obter maior eficiência e rentabilidade.

Em relação à etapa inicial do tráfico desde o sertão até o armazenamento nos portos, ele propõe cinco regras. A primeira deve ter em conta "que os pretos perdendo a sua liberdade ficam desde o começo apaixonados e entregues a um indizível ressentimento." Por isso eles têm de ser tratados "com brandura e agrado, para fazer o cativeiro menos sensível, e desvanecer pouco a pouco o banzo, que não os desacompanha". A segunda consiste em disponibilizar "no rancho, ou lote de escravos (...), um daqueles seus práticos a que chamam curandeiros", para "no decurso da viagem observar as enfermidades e aplicar a medicina do seu uso". Em terceiro vem a prudência de "fazer descansar a escravatura em os sítios mais frescos, e oportunos, onde houverem melhores águas e mantimentos (...), regulando a viagem sempre de tal modo que um dia fosse de marcha e outro de descanso". Nessa mesma regra também é prudente "transportar em odres a água necessária (...) para se fugir à grande e extraordinária sede, e serem prevenidos as muitas enfermidades a que ela dá origem". E o mesmo deve-se praticar sobre os mantimentos, para que nas jornadas fossem os escravos mantidos e sustentados, quando não fosse com fartura, pelo menos com o preciso, para se evitarem as grandes fomes, que de contínuo experimentam em tão longas jornadas". De modo que "os infelizes escravos não venham a um tempo sentir as muitas calamidades provenientes da mudança do clima, das águas, da fatigação da jornada, do sol a que vêm expostos, da

${ }^{4}$ No caso português, tal racionalidade é discutida, entre outros autores, por Novais, 1995, capítulo IV e Maxwell, 1997, capítulo VII. 
| 222 |

Os relatos de Luiz Antônio...

fome e sede". A quarta regra impõe a obrigação de "cortar das fazendas levados para permutação o que fosse preciso, para que com ele o miserável escravo de noite se cobrisse, para deste modo resistir aos efeitos do sereno da noite". Deve-se também "cortar algum mato em aqueles sertões para camas, o que com a maior facilidade se pode fazer em aqueles países desertos e abundantes de arbustos, cujas folhas secas somente usam para esse fim", de modo a proporcionar a escravatura melhor descanso e proteção contra a umidade da terra. A quinta e última regra é fazer conduzir ao lado dos libambos "certa porção de escravatura mansa (...) para diariamente ir caçando para o sustento não apenas de si próprio, mas também de toda a caravana" de forma que "chegado ela ao lugar do arraial [onde se faz pouso], venha frequentemente a ter carne fresca" (Mendes, 1991, p. 35-6).

Em relação ao tempo que os comboiados ficavam nos armazéns do litoral africano à espera do embarque para o cativeiro, Mendes, em tom de denúncia, expressou-se da seguinte maneira:

O que vem a ser mais lastimável é que chegando a tal, e qual porção da escravatura salva aos portos para o embarque, aonde tudo abunda, como por exemplo em S. Paulo de Luanda, devendo-se a tudo isto ocorrer, pelo contrário é a escravatura mantida em a mesma economia, e falta do seu preciso; porque os comerciantes ali estabelecidos, que se entregam à negociação de escravos, insistem em o seu errado sistema, de que quanto mais pouparem no sustento, e tratamento da escravatura, muito mais vêm lucrar em a negociação dela: sem se desenganarem, até pela própria experiência, de que continuando nesta mesquinhez, e economia, tão mal entendida, como mal aplicada, que infinitos escravos sucessivamente lhes morrem vindo neste sentido a ser homicida deles (Mendes, 1991, p. 37).

Aos capitães dos negreiros, várias recomendações são feitas na Memória. "Deveriam ter por cautela transportar melhor a escravatura", ao embarcar menor número dela. "Isso a desafogaria 
de tanto aperto nos porões e, ao mesmo tempo, proporcionaria maior espaço para mais mantimentos e água", sem que continuasse a experimentar novas fomes e sedes por efeito de uma escassa ração e de uma escassa medida de água, que de vinte em vinte e quatro horas se lhes dá. O contrário, "embarcando muitos, muitos também morrem, e abafando uns aos outros enfermam; e ainda aqueles que vêm a ficar salvos, para sempre se conservam enfezados, e doentes, vindo em terra a falecer". Muito contribuiria igualmente para evitar esse desfecho trágico "a providência de fazer embarcar não só mantimentos bons, mas também estes com abundância", ao invés de gêneros "avariados, que, seguindo o mais barato, se compram nos Portos da América" para reduzir os custos da "infeliz negociação", que os levam à África. Desse modo evitariam que "a desgraçada escravatura a um tempo [viria] a sentir dois males: "A fome, dada a escassez de alimentos, e o mal estar provocado pela má qualidade deles"; ambos "danosos à saúde". A mesma providência devem lhes tomar com a água, que deveria ser servida com abundância, para saciar a sede dos embarcados "aumentadas por muitos e diversos modos": por causa "de peixe salgado, que lhes cabe em ração, porque vem abotecada em uma coberta, em que está em perene suor e pela ardência do clima, e da estação, em que são transportados. Por fim, conduzi-los em embarcações mais espaçosas, com ventilação apropriada e facilmente penetrada pelos raios do sol e construídas de forma a evitar tanta invasão de água da chuva (Mendes, 1991, p. 39-40).

Uma vez que "os capitães e os senhorios dos navios são teimosos em o seu projeto, aliás errado, de economia, com o sacrifício de vidas de muitos escravos", o autor da Memória faz uma sugestão à coroa:

Seria a última das providências, que os navios, quando fossem despachados para este fim, tanto em os portos da sua saída, como nos da recepção dos escravos, fossem lotados com taxa, e determinação das cabeças, que pelo muito deviam transportar; sem que a mais se desse licença: com um rigoroso exame em os viveres, e na aguada precisa; subsistindo a cominação, de que 
$|224|$

Os relatos de Luiz Antônio...

\begin{abstract}
trazendo maior número, do que o de sua lotação, seriam além de castigados com penas arbitrárias, condenados a sofrerem o prejuízo de serem manumitidos os últimos escravos, que embarcaram, e que excederam o número prefixo; pois se abusa grandemente da Lei 18 de Março de 1684, inserta na Col. I, n. 3, à Ordenação, L. IV, tit. 42 (Mendes, 1991, p. 41).
\end{abstract}

A lei citada refere-se à determinação de cada embarcação respeitar a capacidade máxima de escravos, carreando de 2,5 a 3,5 indivíduos por tonelada, conforme as características de sua estrutura, bem como a proporção de água e mantimentos que deveriam ser embarcados de acordo com a quantidade de carga e do tamanho da tripulação. Como ela geralmente não era cumprida, os africanos chegavam em condições muito adversas para seguirem rumo ao cativeiro, conforme ele argumenta: "Militando pois todo este tropel de desgraças contra os infelizes escravos; se a tudo eles resistem, e salvam em os países americanos, os que ali aportam, vêm a ser um resto da escravatura, do que homens". Ao contrário disso, se fosse tratada com as devidas cautelas e providências, ainda adverte: "Dentro de poucos dias seria vista sã e forte" e, assim, "com visível interesse, porque a reputariam por muito melhor preço, e vendendo-a logo". E para reforçar seus argumentos sobre a maior vantagem econômica, que se poderia obter na relação entre melhor tratamento do escravo posto em oferta e o maior preço de sua venda, expõe duas observações próprias feitas no Brasil, que julga "constantíssimas a todos que lá viveram por alguns anos, e ainda mesmo aos que lá somente passaram". Na primeira delas, diz: "Observei que comprando qualquer sujeito um escravo (...), tratando-o como coisa sua, com frutas e comidas sadias, e finalmente despendendo com ele todo o bom, dentro de poucos meses aparece um escravo robusto e trabalhador" (Mendes, 1991, p. 42). Na segunda afirma:

Observei mais em aquele país, que homens havia de poucas posses, que se empregavam em comprar o remanescente da escravatura, a que já o comissário 
não tinha comprador, e refugada por todos, não a querendo nem fiada os senhores dos engenhos; não sabendo finalmente já o comissário, que saída havia de dar a ela: sendo este refugo por aqueles comprado levando-o para sua casa, medicando-o, e dando-lhe o sustento, e o vestuário preciso, e fazendo-o mudar de ares; convalescendo a mesma escravatura desprezada, dentro de pouco tempo a revendiam como sã, robusta, e forte por um muito bom preço: e que neste tráfico continuavam, entregando-se a um novo gênero de indústria, chegando até para este fim a comprá-la fiada, vindo a pagá-la com o preço da mesma escravatura sarada, e restabelecida (Mendes, 1991, p. 42-3).

A última parte do capítulo final é dedicada aos "meios de acautelar e remediar as enfermidades" dos escravos. Se todas as precauções sugeridas fossem colocadas em prática pelos agentes da escravidão, desde o tráfico até a América, os índices de mortalidade da população escrava seriam diminuídos. Mas para isso uma verdadeira reforma dos costumes deveria ser promovida por todos os que foram tocados pela exortação dos enciclopedistas (no artigo humanidade: "Percorrer o mundo para combater suas desgraças" $),{ }^{5}$ a fim de ao menos abrandar as crueldades de uma já rigorosa escravidão.

Assim, a parte final do capítulo conclusivo é endereçada principalmente ao grande proprietário no Brasil, como forma de oferecer a ele, na administração dos seus escravos, meios para preservar a saúde destes. Trata-se de uma tentativa de reorientar seu comportamento no governo da escravaria, em relação ao tratamento dela, o qual sendo bem conduzido reduziria

${ }^{5}$ Enciclopédie ou Dictuinnaire Raesonné des Sciences, des Arts et Métiers. 2a ed.,Lucques, Chez Vicent Giuntini. Tomo VIII, 1766, p.285. A definição apresentada no artigo é a seguinte: “Um sentimento de benevolência por todos os homens, que se exalta somente em uma alma grande e sensível. Esse nobre e sublime entusiasmo se atormenta com as penas dos outros, com a necessidade de mitigá-los. Ele quer percorrer o universo para abolir a escravidão, a superstição, o vício e a desgraça". 
$|226|$

Os relatos de Luiz Antônio...

a necessidade de gasto com médico, que era quase sempre evitado caso o seu custo não compensasse o benefício.

De todas as considerações médicas apresentadas na Memória, a que mais vale a pena abordar, por revelar uma das questões centrais sobre a administração dos escravos, é o banzo; "gravíssima enfermidade, que surda e insensivelmente abrasando e consumindo a escravatura, a vai fielmente entregar a morte."

O banzo é outra gravíssima enfermidade, que surda, e insensivelmente abrasando e consumindo a escravatura, a vai fielmente entregar à morte. O meio mais pronto, e o mais natural, que quanto pode haver para exterminar esta moléstia de tão péssimas consequências, pois que o seu curativo não pode achar socorros ainda que na melhor medicina, deve ser o excogitar-se tudo quanto possível seja para desterrarse da infeliz escravatura aquela justa paixão, a que se entrega, na cogitação de que vive combatida dos maiores males. Em a difusão deste justo sentimento deve ter o primeiro lugar um trato que seja capaz de a desimaginar, de que ela não vive, e que não fora trazida, para uma positiva desgraça, na qual se acha sepultada: deve ter o segundo lugar comportarem-se os seus senhores para com ela de um modo benigno, e afável, indicando-lhe que se acham bem servidos, inspirando na escravatura os sentimentos, de que têm eles por acerto, e por fortuna a uns bons escravos; para na recompensa nascerem os outros correlativos sentimentos nos escravos, de que tiveram a dita de encontrar a um bom senhor: deve ter o terceiro lugar o moderarem-se os castigos: deve ter o quarto lugar a permissão de ela se divertir e folgar ao seu modo, e ainda com convocação dos seus patriotas e semelhantes; para lhe influir um justo prazer, e a necessária alegria, o que só é capaz de fazer desterrar o banzo e as moléstias fúnebres a que com facilidade se entregam (Mendes, 1991, p. 48). 
Ao concluir a sua exposição sobre os meios preventivos e curativos para melhor preservar a escravaria, para o bem da humanidade, para a grandeza da riqueza do Estado e para a prosperidade dos colonos, Mendes faz a última advertência: "Todas estas enfermidades, que levam escravos à sepultura, seriam evitadas se em tempo fossem tratadas; porém se o mau trato a uma acorda, e as outras promove, (...) vem a servir de aumento aos infinitos males principiados com a escravidão, e ultimados com a fiel entrega dos ossos à terra" (Mendes, 1991, p. 49-50).

Suas palavras finais são, na versão revisada para a publicação em 1812 (aqui utilizada), uma exortação ao poder da Casa Real para, em nome da humanidade e da maior eficiência e rentabilidade expressa na noção de interesse econômico, cada vez mais em voga na época, combater todos os abusos cometidos pelos agentes da escravidão contra os que para ela foram arrastados. Já na versão original, lida na Academia Real das Ciências de Lisboa em 1793, suas palavras são bem mais contundentes: "O céu, a terra, a humanidade e a mesma Real Coroa, para a resistência destes abusos pede vingança." ${ }^{6}$

\section{Seria Mendes um antiescravista?}

A postura de Mendes relatada no tópico anterior, principalmente em suas palavras finais faz de Mendes ser considerado um antiescravista, como acredita Ana Maria Goldini Raimundo Oda, apoiada em um estudo de Robert Slenes (Oda, 2007, p. 359 e Slenes 2002). Ou podemos interpretar que as suas últimas palavras de Mendes são apenas frases de efeito para provocar inquietação nos seus interlocutores, estimulando um debate sobre tema que se tornava bastante delicado na cultura ocidental? Convém lembrar que em alguns trechos da Memória, ele também se revela um conselheiro dos agentes da escravidão, ${ }^{6}$ A versão de 1812 está em Mendes, 1991, p. 50. A citação da versão de 1798
é fornecida por Oda, 2007, p. 359. 
$|228|$

Os relatos de Luiz Antônio...

sobretudo no cativeiro, ao sugerir que os africanos se tornariam bons escravos se fossem bem tratados. Mas isso seria suficiente para considerá-lo apenas um divulgador de "cuidados humanitários e médicos, no âmbito de uma mais vasta terapêutica social", como afirma o organizador da edição dos textos da Academia Real das Ciências de Lisboa, José Luís Cardoso, ao concluir que, na Memória, “a legitimidade da escravidão não é questionada, [pois] em causa está o modo de a tornar efetivamente rentável"?

Seria necessário investigação mais profunda sobre a vida e a obra de Mendes, para se chegar a uma resposta. E isso pode ser iniciado com pistas por ele deixadas no seu texto. Uma delas encontra-se no final da Memória, quando afirma somente lhe restarem duas conclusões: a de que a mortandade dos escravos é fruto dos maus tratos dos agentes da escravidão e a de que em nome da humanidade e dos interesses da Coroa isso deveria ser combatido. Depois disso escreveu uma nota (no 29) na qual escreveu o seguinte: "Assim como se omite o que neste discurso poderia dizer-se de considerações morais, mas deve ler-se nos sermões 14o, 20o, 27o do Rosário" (Mendes, 1991, p. 50).

Na nota a referência clara são os Sermões do Padre Vieira, compostos de prédicas morais, proferidas na Bahia entre 1633 e 1680. Os acima citados foram destinados aos escravos e seus senhores, e seu tema principal é a escravidão. Neles o jesuíta aborda o tratamento recebido pelos negros no cativeiro, condenando a falta de espírito cristão por parte dos proprietários dos engenhos baianos. Ao fazer isso, procurou tocar as consciências senhoriais, para melhorar a condição dos cativos, lembrando que a justiça divina é implacável. Por outro lado, empenhou-se para exortar a escravatura a conformar-se com a sua condição servil, como meio de encontrar a salvação eterna.

Ainda não é possível saber qual a leitura Mendes fez das prédicas de Vieira. Mas ao citá-las, apenas pode estar em busca de um reforço de peso para sustentar a imagem perversa das práticas

\footnotetext{
7 O comentário de José Luis Cardoso está na nota b da p. 9 de Mendes
} (1991). 
escravistas vigentes, que tanto se esforçava para ajudar a mudar. $\mathrm{Ou}$, mais do que isto, insinuar que, apesar da riqueza das nações ainda depender do trabalho escravo, já não podia sustentála por muito maior tempo, dada a sua cada vez mais clara incompatibilidade com os velhos ideais cristãos de amor ao próximo e com os novos ideais iluministas de civilização, progresso e humanidade.

O certo é que ele, como um ilustrado, membro de uma instituição científica patrocinada pela Coroa (um savant d'etat, ${ }^{8} \mathrm{ou}$, por que não dizer, um intelectual orgânico?), se fosse claramente partidário do abolicionismo, não ousaria revelar- se como tal em texto para ser lido em sessão solene da Academia Real de Ciências de Lisboa, uma vez que um dos grandes objetivos práticos desta instituição era o de promover o progresso material do império de Portugal, em adiantada crise naqueles tempos (Schwarcz, 2002, p. 65). Por outro lado, se a legitimidade da escravidão não estava explicitamente questionada na sua Memória, a sua natureza ao menos estava sendo repugnada, devido à forma como escreveu, usando um novo padrão de escrita (denominada narrativa humanitária), por meio do qual se fazia grande esforço para conquistar o leitor para uma causa, estimulando-lhe o sentimento de compaixão. Desse modo, pode-se considerá-lo um combatente intelectual de uma cruzada moral promovida, a partir do movimento ilustrado da Era das Luzes, por todos os que se sentiram sensibilizados com a brutalidade de uma relação social de produção fundamentada na expropriação violenta da liberdade humana.

\footnotetext{
${ }^{8}$ Ou savant du ancien régime é uma noção, definida como um intelectual que atuava nas instituições de Estado, aceitando os valores e hierarquias de uma sociedade regida pelo onipresença das honras e dos privilégios como forma de diferenciar os seus indivíduos, formulada por Vicenzo Ferrone, "O homem de ciência". In Vovelle, 1997, p. 159. Em outras palavras, trata-se do clássico conceito gramisciniano de "intelectual orgânico" adaptado por Ferrone às sociedades do Antigo Regime.
} 


\section{Referências}

CIDADE, H. Padre Vieira (Sermões). Lisboa, volume III, 1940.

CHALHOUB. S. Cidade febril. São Paulo, Cia das Letras, 1999.

CONRAD, R. E. Tumbeiros: o tráfico de escravos para o Brasil. São Paulo, Brasiliense, 1985.

FERRONE, V. O homem de ciência. In: VOVELLE, Michel, O homem do Iluminismo. Lisboa, Editorial Presença, 1997.

FREIREYSS, G. W. Viagem ao interior do Brasil. Belo Horizonte, ed. Itatiaia, 1992

HONORATO, C. de P. Valongo: o mercado de escravos no Rio de Janeiro. Dissertação de mestrado em história, Universidade Federal Fluminense, 2007.

KLEIN, H. O tráfico de escravos no Atlântico. Ribeirão Preto, Funpec, 2004.

MARQUESE, R. de B. Feitores do corpo, missionários da mente: senhores, letrados e o controle dos escravos nas Américas. São Paulo, Cia. das Letras, 2004.

MAXWEL, K. Marquês de Pombal: paradoxo do Iluminismo. Rio de Janeiro, Paz e Terra, 1997.

MENDES, L. A. de O. Memória a respeito dos escravos e do tráfico de escravatura entre a Costa da África e o Brasil. In: Memórias Econômicas da Academia Real de Ciência de Lisboa. Tomo IV. Direção José Luis Cardoso. Lisboa, [ 1812] 1991.

NOVAIS, F. Portugal e Brasil na crise do sistema colonial. 6a ed., São Paulo, Hucitec, 1995.

ODA, A. M. G. R. O banzo e outros males: O páthos dos negros na memória de Oliveira Mendes, Revista Latino-americana de Psicopatologia fundamental. v.10, no 2, 2007.

PEREIRA, J. C. da S. A flor da terra: o cemitério dos pretos novos do Rio de Janeiro. Rio de Janeiro, Garamond/IPHAN, 2007. 
SILVA, A. da C. e. Memória histórica sobre os costumes particulares dos povos africanos. Afro-Ásia, v.28, 2002,

SLENES, R. African, Lucretias and Men of Sorrows: Allegory and Allusion in the Brazilian Anti-slavery (Lithographis) (18271835) of Johann Moritz Rugendas. In: Slavery and Abolition, v.23, 2002.

VOVELLE, M. O homem do Iluminismo. Lisboa, Editorial Presença, 1997. 